\title{
EFFECT OF SOWING DATE ON GROWTH AND YIELD OF FOUR RADISH (RAPHANUS SATIVUS L .) VARIETIES
}

\author{
Amur A. H . Al-juboori Shamil . Y . H . Al-hamdani Merwa . M . Hamdon \\ College of Agriculture and forestry University of Mosul, Mosul Iraq . \\ Email: al-juboori1963@yahoo.com
}

\begin{abstract}
An experiment was conducted in the Vegetable field of Horticulture and landscape Department College of Agriculture and Forestry University of Mosul, during the growing season of $(2018$ - 2019) to study the effect of sowing dates (20th Oct; 10th Nov) on growth and yield of four radish varieties Red Local (V1); Black Local (V2); Turkish (V3) and Syrian (V4) of radish All the growth parameters such as, number of leaves, leaf area, root-shoot ratio plant weight, root weight, root length, root diameter, yield of $\operatorname{root}(24.703) \mathrm{t} \mathrm{h}-1$ were significantly increased with sowing 20th Oct compared with other sowing dates.

The effect of varieties Surry superior in Root weight (152.43 g) and root to shoot ratio (2.07) and diameter of root $(7.00 \mathrm{~cm})$ and total root yield $(25.4 \mathrm{t} \mathrm{h}-1)$ compared with other varieties. Interaction between sowing dates and varieties showed that sowing on 20th Oct significant on growth and yield such as Number of leaves per plant, Leaf area and root yield. The fresh weight of leaves was supreme $(176.97 \mathrm{~g})$ in Black Local, and root length $(8.63 \mathrm{~cm})$.

Key words: Sowing dates of radish, varieties radish .
\end{abstract}

Received :25/3/2019 Accepted :10/10/2019

\section{INTRODUCTION}

Radish (Raphanus sativus L.), which belongs to family Brassicacae is the most popular and widely grown vegetable in both tropical and temperate regions. Radish is grown for its tender fleshy edible roots. originated from the Central and Western China and India (Thamburaj and Singh, 2005). It is one of the most ancient vegetable. It is an annual or biennial crop depending upon the type for the purpose it is grown (Pcarrd, 2009).

In Iraq it is widely cultivated in Northern and Southern plains, as well as in hills. Radish is grown for its young tender tuberous root which is consumed either raw as salad or cooked as a vegetable. it has cooling effect, prevents constipation and increases appetite. It is recommended for patients suffering from piles, liver troubles and jaundice. The juice of fresh leaves is used as diuretic and laxative, characteristics pungent flavour of radish is due to presence of volatile isothiocyanates (Bose et al., 2000). which helps in digestion The leafy tops are rich in calcium, potash, phosphorus and vitamin C containing 34-40 mg per $100 \mathrm{~g}$ of edible portion and very refreshing when eaten fresh vitamins like A, B and C and posses little quantity of carbohydrates, iron and proteins (Nath et al., 1987) and (Kanwar, 1993).

One of the factors responsible for reduced growth and lower yield of vegetables is cultural practices like time of sowing and cultivars. The scientific vegetable production reveals the significance and importance of sowing dates and varieties to 
be used for raising vegetable crops in order to get higher production of good quality vegetables. including the vegetative and reproductive growth periods as well as the balance between them, which affects yield. An appropriate sowing date helps reduce damage from cold, heat, pests, diseases, and weeds. Growers often manipulate sowing times for better growth and yields (Alam et al., 2010, Sandler et al., 2015). therefore, late planting decreases the most important traits i.e. days to flowering, duration of flowering, plant height and yield per plant which cause a remarkable reduction in yield (Rameeh, 2012).

the maintenance of optimum plant and planting time offers ample scope for increasing the flowering, fruiting and seed yield of radish (Kumar et al., 2012). There are few recommendations that sowing date and variety have brought classical changes in growth and root yield of radish crop with economical returns (Lavanya et al., 2014).. Early sowing recorded maximum vegetative growth and higher yield than late planting (Alam et al.,2010). Pandey et al. (2009) investigated 10 radish varieties with four dates of sowing at an interval of 10 days The maximum length of root $(24.54 \mathrm{~cm})$ was obtained on 2 nd date of sowing Among all the four dates of sowing, the minimum length of root $(22.31 \mathrm{~cm}$.) was recorded at final date of sowing.

for low production of the radish in farmer's field is lack of knowledge on suitable varieties (Gautam and Khatiwada, 1997). Among these factors variety is a predominant. Several varieties of radish are available in the market having varying length, size, colour, taste, yield potential and quality parameters.

experiment objectives:

To study the effect of planting date on yield of radish. and evaluate the effect of variety on yield and quality of radish. also to assess the interactive effect of date of planting and variety on yield and quality of radish.

MATERIALS AND METHODS

Field experiment was conduced at the Horticulture and landscape design department. College of Agriculture and Forestry, Mosul University, during the growing season of $(2018$ - 2019). To study the effect sowing date (D) (20 Oct, 10 Nov) on growth and yield for four radish varieties Red Local(V1), Black Local (V2), Turkish (V3) and Syrian (V4)) of radish

Two factorials experiment were laid out following a Randomized Complete Block design (RCBD) with three replications. Each block divided into eight rows allotted at random. Thus there were 24 rows in the experiment. distance between two block $50 \mathrm{~cm}$. plant grown under rows by length $3 \mathrm{~m}$ and width $70 \mathrm{~cm}$ and between the plants on the rows $30 \mathrm{~cm}$. the plants fertilizers by nitrogen were applied as per the recommendations mean $(150-200) \mathrm{kg} / \mathrm{h}$ (Jilani et al 2010). Seeds sown at the rate of $9 \mathrm{~kg} / \mathrm{ha}$ in about $1.5 \mathrm{~cm}$ depths in lines continuously and covered by loose soil. 20-20 days after its emergence. seedlings were thinned out by retaining one at each hill.

The other cultural practices like irrigation, weeding, ear thing up and plant protection operation were carried out as and when required. Crop was harvested after 50 - 65 days and estimate of the varieties. the Syrian harvested after 50 days and Red Local 55 days follow Turkish 60 days finally Black Local. use program 
SAS (2001) at statistical analysation on data. adjectives measurements (Plant height $(\mathrm{cm})$, Number of leaves/plant, leaf area, Fresh Weight of vegetative $(\mathrm{g})$, Root weight(g), Root length (cm), root width $(\mathrm{cm})$, Ratio Root/Shoot, yield t/ha.

\section{RESULTS AND DISCUSSION}

1 - Effect of planting dates on the vegetative growth of radish.

Data in Table (1) show the superiority of plants grown on the date 20 October in the adjectives number of leaves per plant, the leaf area per plant and the fresh weight of leaves compared with the lowest values of the cultivated plants under the planting date 10 November, which gave the lowest values in those characteristics These results correlate with (Alam et al. 2010) and (Panwar et al 2013).

Table (1): Effect of planting date on growth of radish

\begin{tabular}{|c|c|c|c|c|c|}
\hline D & $\begin{array}{c}\text { Root weight } \\
(\mathrm{g})\end{array}$ & $\begin{array}{c}\text { Root length } \\
(\mathrm{cm})\end{array}$ & $\begin{array}{c}\text { Root diameter } \\
(\mathrm{cm})\end{array}$ & $\begin{array}{c}\text { Ratio Root } \\
/ \text { shoot }\end{array}$ & $\begin{array}{c}\text { yield } \\
\text { t/ha }\end{array}$ \\
\hline $20 \mathrm{Oct}$ & $148.08 \mathrm{~A}$ & $7.54 \mathrm{~A}$ & $7.57 \mathrm{~A}$ & $1.57 \mathrm{~A}$ & $24.70 \mathrm{~A}$ \\
\hline $10 \mathrm{Nov}$ & $65.36 \mathrm{~B}$ & $5.67 \mathrm{~B}$ & $4.97 \mathrm{~B}$ & $1.35 \mathrm{~A}$ & $10.89 \mathrm{~B}$ \\
\hline
\end{tabular}

2 - Effect of planting dates on yield of radish.

Table (2) shows the results of the analysis of the studied traits, where the cultivated plants on 20 October exceeded the characteristics of the yield of root weight, length, root diameter $(\mathrm{cm})$ and total yield $\mathrm{t} / \mathrm{h}$. This he found ( Rao, Manhar 1990), (Malik et al. 1999), (Karbalaei et al. 2012) and (Kanwar et al 2013) Compared to the lowest values of cultivated plants on10 November, when the plant yield began to decline gradually. These results are similar to those found (Sharma et al. 2007) and (Kabir et al. 2013) on carrot.

Table (2): Effect of planting date on yield of radish

\begin{tabular}{|c|c|c|c|c|c|}
\hline D & $\begin{array}{c}\text { Root weight } \\
(\mathrm{g})\end{array}$ & $\begin{array}{c}\text { Root length } \\
(\mathrm{cm})\end{array}$ & $\begin{array}{c}\text { Root diameter } \\
(\mathrm{cm})\end{array}$ & $\begin{array}{c}\text { Ratio Root } \\
\text { /shoot }\end{array}$ & $\begin{array}{c}\text { yield } \\
\text { t/ha }\end{array}$ \\
\hline $20 \mathrm{Oct}$ & $148.08 \mathrm{~A}$ & $7.54 \mathrm{~A}$ & $7.57 \mathrm{~A}$ & $1.57 \mathrm{~A}$ & $24.70 \mathrm{~A}$ \\
\hline $10 \mathrm{Nov}$ & $65.36 \mathrm{~B}$ & $5.67 \mathrm{~B}$ & $4.97 \mathrm{~B}$ & $1.35 \mathrm{~A}$ & $10.89 \mathrm{~B}$ \\
\hline
\end{tabular}

3 - Effect of the variety on vegetative growth of radish.

The results of the analysis in Table (3) showed that there were no significant differences for most of the studied traits in the experiment except for the fresh weight of leaves Where the superiority of the local black In that adjectives to most of the varieties and perhaps This is due to genetic differences between species where the results of the investigation are similar to those reached (Mapari et al., 2009). 
Table (3): Effect of variety on vegetative growth of radish

\begin{tabular}{|c|c|c|c|c|}
\hline V & $\begin{array}{c}\text { Plant height } \\
(\mathrm{cm})\end{array}$ & $\begin{array}{c}\text { No of leaves } \\
\text { /plant }\end{array}$ & $\begin{array}{c}\text { Leaf area } \\
\mathrm{Cm}^{2}\end{array}$ & $\begin{array}{c}\text { fresh weight } \\
\text { of leaves }(\mathrm{g})\end{array}$ \\
\hline V1 & $31.13 \mathrm{~A}$ & $10.72 \mathrm{~A}$ & $1095.0 \mathrm{~A}$ & $67.60 \mathrm{~B}$ \\
\hline V2 & $34.82 \mathrm{~A}$ & $10.43 \mathrm{~A}$ & $1113.6 \mathrm{~A}$ & $119.70 \mathrm{~A}$ \\
\hline V3 & $29.50 \mathrm{~A}$ & $10.80 \mathrm{~A}$ & $1076.5 \mathrm{~A}$ & $66.32 \mathrm{~B}$ \\
\hline V4 & $31.48 \mathrm{~A}$ & $9.85 \mathrm{~A}$ & $1197.9 \mathrm{~A}$ & $68.03 \mathrm{~B}$ \\
\hline
\end{tabular}

4 - Effect of variety on yield of radish.

From table (4) we observe the superiority of the Syrian cultivars in the characteristics of root weight, root diameter, rooting percentage and total yield $\mathrm{t} / \mathrm{h}$ on most of the other varieties in the experiment According to his findings (Dongarwar et al., 2017), compared with the lowest values in the plant yield of local red varieties. These results are identical to those obtained (Dongarwar et al., 2018). While the superiority of local black varieties in length of the root on the most of the other varieties in the experiment.

Table (4): Effect of variety on yield of radish

\begin{tabular}{|c|c|c|c|c|c|}
\hline V & $\begin{array}{c}\text { Root weight } \\
(\mathrm{g})\end{array}$ & $\begin{array}{c}\text { Root length } \\
(\mathrm{cm})\end{array}$ & $\begin{array}{c}\text { Root diameter } \\
(\mathrm{cm})\end{array}$ & $\begin{array}{c}\text { Ratio Root/ } \\
\text { shoot }\end{array}$ & $\begin{array}{c}\text { yield } \\
\text { t/ha }\end{array}$ \\
\hline V1 & $80.47 \mathrm{~B}$ & $5.73 \mathrm{~B}$ & $6.77 \mathrm{~A}$ & $1.23 \mathrm{BC}$ & $13.5 \mathrm{~B}$ \\
\hline $\mathrm{V} 2$ & $88.37 \mathrm{~B}$ & $7.67 \mathrm{~A}$ & $4.83 \mathrm{~B}$ & $0.87 \mathrm{C}$ & $14.8 \mathrm{~B}$ \\
\hline $\mathrm{V} 3$ & $105.62 \mathrm{~B}$ & $6.17 \mathrm{~B}$ & $6.43 \mathrm{~A} \mathrm{~B}$ & $1.67 \mathrm{~B}$ & $17.6 \mathrm{~B}$ \\
\hline $\mathrm{V} 4$ & $152.43 \mathrm{~A}$ & $6.90 \mathrm{~A} \mathrm{~B}$ & $7.00 \mathrm{~A}$ & $2.07 \mathrm{~A}$ & $25.4 \mathrm{~A}$ \\
\hline
\end{tabular}

5 - Effect of interaction on vegetative growth of radish.

Table (5) shows that there is no significant difference in plant height Due to interference Between planting dates and varieties, But there is a response to the varieties when planted under the planting date (20 October) In the number of leaves and leaf area per plant compared to the same varieties under the date (10 November), which gave the lowest values for those adjectives, While the superiority of the category of local black under the planting date of (20 October) In the fresh weight of leaves On the two varieties local Red and Turkish with lowest values under planting date (10 November). 
Table (5): Effects of interaction on vegetative growth of radish

\begin{tabular}{|c|c|c|c|c|c|}
\hline D & V & $\begin{array}{c}\text { Plant height } \\
(\mathrm{cm})\end{array}$ & $\begin{array}{c}\text { N. of leaves } \\
\text { /plant }\end{array}$ & $\begin{array}{c}\text { Leaf area } \\
\mathrm{Cm}^{2}\end{array}$ & $\begin{array}{c}\text { fresh weight } \\
\text { of leaves(g) }\end{array}$ \\
\hline \multirow{3}{*}{$20 \mathrm{Oct}$} & $\mathrm{V} 1$ & $32.60 \mathrm{~A}$ & $12.40 \mathrm{~A}$ & $1379.9 \mathrm{~A}$ & $89.00 \mathrm{~B}$ \\
\cline { 2 - 6 } & $\mathrm{V} 2$ & $36.97 \mathrm{~A}$ & $11.83 \mathrm{~A}$ & $1359.2 \mathrm{~A}$ & $176.97 \mathrm{~A}$ \\
\cline { 2 - 6 } & $\mathrm{V} 3$ & $29.67 \mathrm{~A}$ & $12.07 \mathrm{~A}$ & $1403.6 \mathrm{~A}$ & $87.33 \mathrm{~B}$ \\
\cline { 2 - 6 } & $\mathrm{V} 4$ & $32.97 \mathrm{~A}$ & $10.83 \mathrm{~A} \mathrm{~B}$ & $1541.1 \mathrm{~A}$ & $87.90 \mathrm{~B}$ \\
\hline \multirow{3}{*}{$10 \mathrm{Nov}$} & $\mathrm{V} 1$ & $29.67 \mathrm{~A}$ & $9.03 \mathrm{~B}$ & $810.0 \mathrm{~B}$ & $46.20 \mathrm{C}$ \\
\cline { 2 - 7 } & $\mathrm{V} 2$ & $32.67 \mathrm{~A}$ & $9.03 \mathrm{~B}$ & $868.1 \mathrm{~B}$ & $62.43 \mathrm{BC}$ \\
\cline { 2 - 7 } & $\mathrm{V} 3$ & $29.33 \mathrm{~A}$ & $9.53 \mathrm{~B}$ & $749.3 \mathrm{~B}$ & $45.30 \mathrm{C}$ \\
\cline { 2 - 7 } & $\mathrm{V} 4$ & $30.00 \mathrm{~A}$ & $8.87 \mathrm{~B}$ & $854.7 \mathrm{~B}$ & $48.17 \mathrm{BC}$ \\
\hline
\end{tabular}

6 - Effect of interaction on yield of radish.

Results in Table (6) show the superiority of cultivated plants under the date of cultivation(20 October) of the cultivar syrian With the best values in the characteristics of root weight, root diameter and total yield $\mathrm{t} / \mathrm{h}$ According to his findings (Priyanka et al 2018), While the superiority of the category local black under the date (20 October) In root length compared to the lowest root value of local red varieties under planting date (10 November) While plants of the Syrian variety cultivated under the date (10 November) exceeded the rate of rooting On the black cultivar cultured under the date of cultivation (20 October), which gave the lowest values in that adjectives.

Table (6): Effects of interaction on yield of radish

\begin{tabular}{|c|c|c|c|c|c|c|}
\hline $\mathrm{D}$ & $\mathrm{V}$ & $\begin{array}{c}\text { Root weight } \\
(\mathrm{g})\end{array}$ & $\begin{array}{c}\text { Root length } \\
(\mathrm{cm})\end{array}$ & $\begin{array}{c}\text { Root diameter } \\
(\mathrm{cm})\end{array}$ & $\begin{array}{c}\text { Ratio Root } \\
/ \text { shoot }\end{array}$ & $\begin{array}{c}\text { yield } \\
\mathrm{t} / \mathrm{ha}\end{array}$ \\
\hline \multirow{3}{*}{$20 \mathrm{Oct}$} & $\mathrm{V} 1$ & $122.17 \mathrm{BC}$ & $7.10 \mathrm{ABC}$ & $8.03 \mathrm{~A}$ & $1.61 \mathrm{BC}$ & $20.36 \mathrm{BC}$ \\
\cline { 2 - 7 } & $\mathrm{V} 2$ & $137.87 \mathrm{~B}$ & $8.63 \mathrm{~A}$ & $6.43 \mathrm{AB}$ & $1.11 \mathrm{CD}$ & $23.07 \mathrm{~B}$ \\
\cline { 2 - 7 } & $\mathrm{V} 3$ & $134.33 \mathrm{~B}$ & $6.70 \mathrm{BC}$ & $7.43 \mathrm{AB}$ & $1.51 \mathrm{BC}$ & $22.38 \mathrm{~B}$ \\
\cline { 2 - 7 } & $\mathrm{V} 4$ & $197.97 \mathrm{~A}$ & $7.73 \mathrm{AB}$ & $8.17 \mathrm{~A}$ & $1.93 \mathrm{AB}$ & $32.99 \mathrm{~A}$ \\
\hline \multirow{3}{*}{$10 \mathrm{Nov}$} & $\mathrm{V} 1$ & $38.77 \mathrm{D}$ & $4.37 \mathrm{D}$ & $5.40 \mathrm{BC}$ & $0.85 \mathrm{D}$ & $6.47 \mathrm{D}$ \\
\cline { 2 - 7 } & $\mathrm{V} 2$ & $38.87 \mathrm{D}$ & $6.60 \mathrm{BC}$ & $3.23 \mathrm{C}$ & $0.63 \mathrm{D}$ & $6.47 \mathrm{D}$ \\
\cline { 2 - 7 } & $\mathrm{V} 3$ & $76.90 \mathrm{CD}$ & $5.63 \mathrm{CD}$ & $5.43 \mathrm{BC}$ & $1.73 \mathrm{AB}$ & $12.83 \mathrm{CD}$ \\
\cline { 2 - 7 } & $\mathrm{V} 4$ & $106.90 \mathrm{BC}$ & $6.07 \mathrm{BC}$ & $5.83 \mathrm{AB}$ & $2.22 \mathrm{~A}$ & $17.81 \mathrm{BC}$ \\
\hline
\end{tabular}

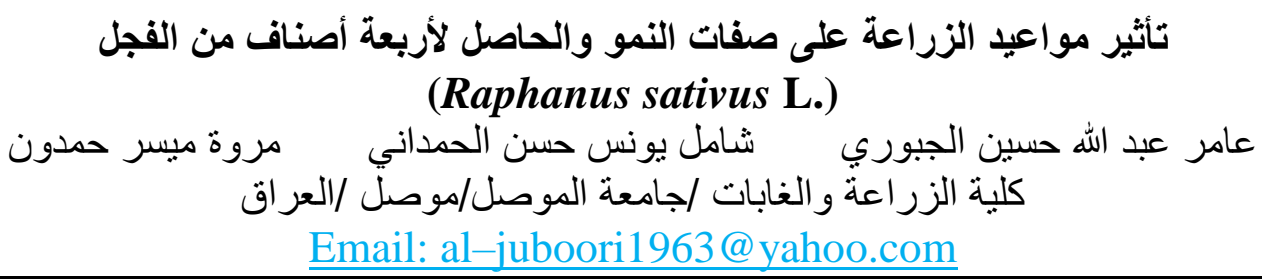

الخلاصة

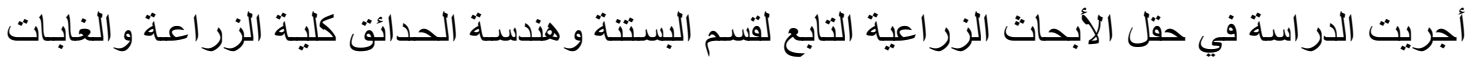

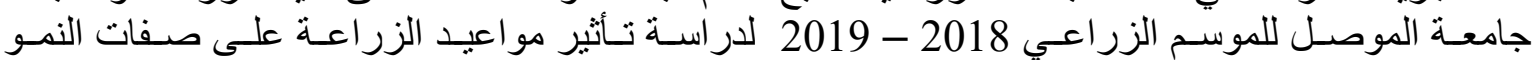


و الحاصل لأربعة أصناف من الفجل ونظمت التجربة بتصميم RCBD بنظام القطع المنشقة وبعاملين هما

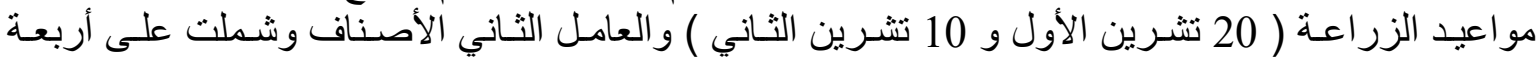

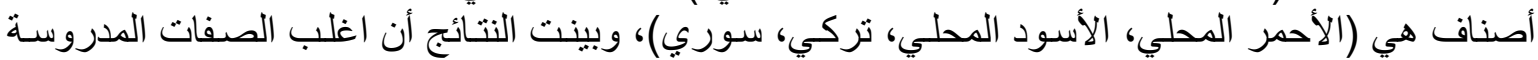

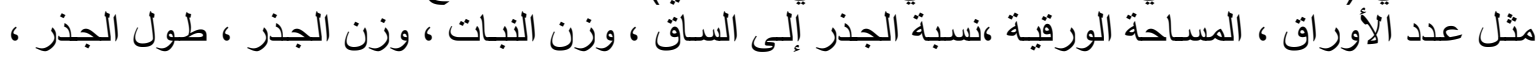

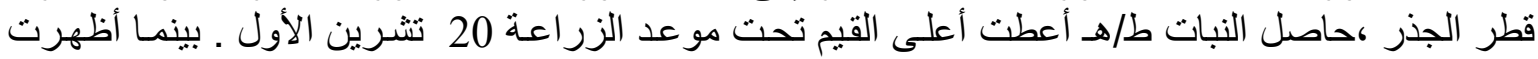

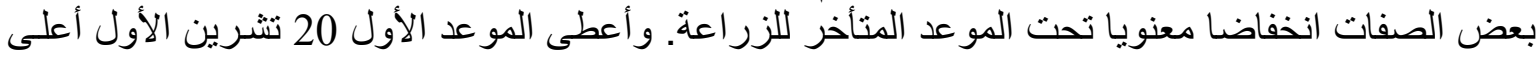

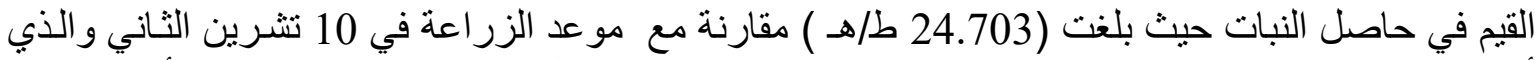

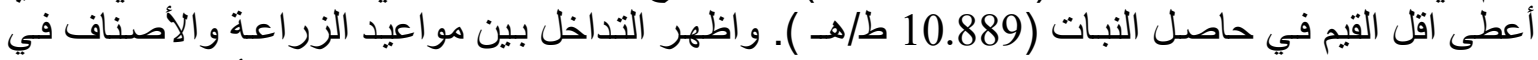

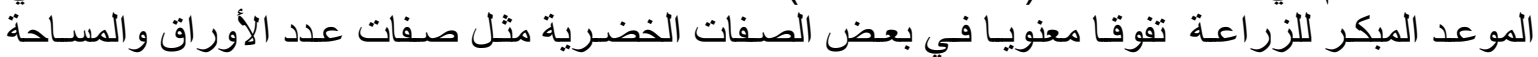

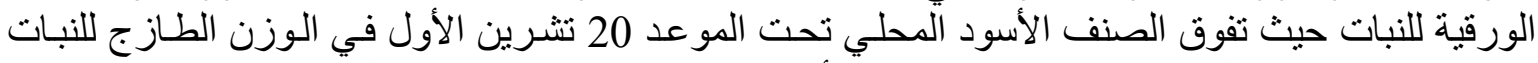

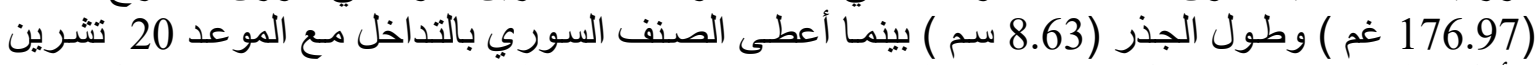

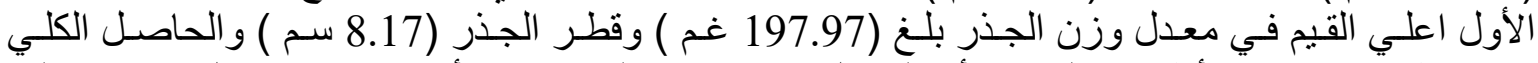

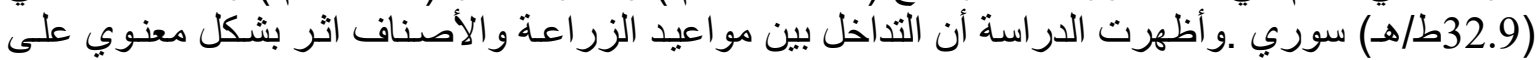

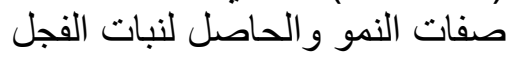

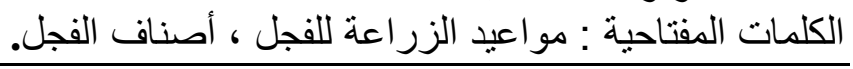

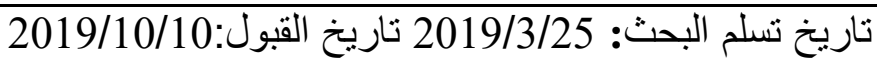

\section{REFERENCES}

Alam M, Farooque AM, Nuruzzaman M and Jamaluddin, AFM. (2010). Effect of sowing time on growth and yield of three radish Raphanus sativus Lvarieties.Bangladesh Research Publications Journal.; 3(3):998-1006.

Anjanappa M, Shiva Reddy N, Murli K, Krishnappa KS. (1998).Performance of certain radish varieties under southern dry region of Karnataka. Karnataka J. Agric. Sci.;11(3):862-864.

Bhat KL. ( 1996). Effect of different levels of nitrogen and phosphorus on yield of different cultivars of radish. Crop Res.;11(2):204-206.

Bose, T.K.; Kabir, J.; Das, P. and Joy, P. P. (2000). Tropical Horticulture. Volume1 Naya Prokash, Calcuta. pp. 145.

Deotale, A.B., P.V. Bilorkar, N.G. Bedvaik, S. R. Patil, and J. R. Rathod, (1994). Studies on performance of some radish (Raphanus sativus L.) cultivars under Nagpur condition. J. Soils and Crops 4(2), 120-121.

Dongarwar L.N. , Sumedh R. Kashiwar, S.M. Ghawade and Usha R. Dongarwar (2017) Performance of Different Radish (Raphanus sativusL.) Varieties in Black Soils of Vidharbha-Maharashtra. International Journal of Plant \& Soil Science. 20(5): 1-9.

Dongarwar L.N., Sumedh R. Kashiwar, S.M. Ghawade and Usha R. Dongarwar (2018).Varietal Performance of Radish (Raphanus sativus L.) Varieties in Black Soils of Vidharbha-Maharashtra, India . Int.J. Curr. Microbiol. App.Sci 7(1): 491-501.

Ebrahimi, M.; Hassandokht,M.R. and Payvast, G.H. (2013). Effect of sowing dates on some quantitative and qualitative traits of three landraces of black radish (Raphanus sativus var. niger). Adv. Environ. Bio. 7(1): 136-140.

Gautam, I. P. and P. P. Khatiwada, (1997). Results on Purification of Bhetedar Local Radish. Working Paper no. 205 Phakirbas Agriculture Center, Dhankuta, Nepal. Pp. 1- 6. 
Gill SS, Gill BS. (1995).Seed yield in radish as influenced by the date of transplanting and steckling size. Seed Research.; 23(1):28-30.

Gill, S. S. and H. Singh (1979). Effect of seed size and sowing dates on germination and yield of radish roots. Seed Res.,7(1) : 58-62.

Kabir, A., Ali, A., Waliullah, M.H., (2013). Effect of spacing and sowing time on growth and yield of carrot (Daucus carrota L.). International Journal of Sustainable Agriculture. 5(1): 29-36.

Kanwar JS. (1993) . Influence of spacing and time of sowing on growth and seed yield of radish. Indian Journal of Agricultural Sciences.; 63(6):351-353.

Kanwar, M. S.; Sharma, O.C. and Akbar, P. I. (2013). Response of sowing System and sowing time on yield and Horticultural Traits of radish (Raphanus sativus L.) in Cold Arids. Bionfolet 10(4B): 1203-1207.

Karbalaei, S, Mehraban, A, Mobasser, H.R. and Bitarafan, Z., (2012). Sowing date and transplant root size effects on transplanted sugar beet in spring planting. Annuals of Biological Research. 3(7): 3474-3478 .

Kumar, R., R. Sharma, R.K. Gupta, and M. Singh, (2012). Determination of genetic variability and divergence for root yield and quality characters in temperate radishes. Int. J. Veg. Sci. 18(4), 307-318.

Lavanya, A. V. N; Vani, V. S.; Reddy, P. S. S. and Chaitanya, K. (2014). Root yield of radish as affected by sowing dates and spacing. Plant Arch. 14(1): 615618.

Malik YS, Nehra BK, Narendra, Singh N. (1999) . Effect of steckling planting dates on seed yield of radish Raphanus Salivus L. Haryana Journal of Horticultural Sciences.; 17(1-2):97-101.

Mapari AV, Dod VN, Peshattiwar PD, Archana Thorat. (2009). Genetic variability in radish. The Asian J. of Hort.;4(2):225-258.

Nath PO, Velayudhan S, Singh DP. (1987).Vegetables For The Tropical Region, ICAR, New Delhi, India.

Pandey, A. K.; Singh, M.; Singh, P. M.; Rai, M. and Singh, T. B. (2009). Influence of sowing dates on vegetative growth, yield and quality of radish (Raphanus sativus L.). Veg. Sci. 36(2): 225-226.

Panwar, N.S, Mishra, A.C, Uniyal, S.P, Pandey, V. and Bali, R.S. (2013). Effect of dates of sowing on yield and quality of radish (Raphanus sativus) cultivars under rain fed mid-hill conditions of Uttarakhand. Annuals of AgroBiotech Research. 18(3): 360-363 .

Pcarrd.(2009). Philippine Recommends for radish production http://www. earthworm. co.za /nutricast/ nutricast- information /http: //www. Capevermicast. com/vermicast .php .

Priyanka . M, K. Swarajya Lakshmi, P. Syam Sundar Reddy, D. Srinivasa Reddy and Sri M. Bala Krishna . (2018) .Interaction Effect of Varieties and Sowing Dates on Growth and Quality of Radish in Southern Agro Climatic Zone of Andhra Pradesh . Int. J. Pure App. Biosci. 6 (5): 227-231 .

Priyanka. M, K. Swarajya Lakshmi, P. Syam Sundar Reddy, D. Srinivasa Reddy and Sri M. Bala Krishna . (2018).Interaction Effect of Varieties and Sowing 
Dates on Growth and Quality of Radish in Southern Agro Climatic Zone of Andhra Pradesh . Int. J. Pure App. Biosci. 6 (5): 227-231.

Rameeh, V. (2012).Evaluation of the planting dates effects on yield and yield associated traits in rapeseed advanced lines. Int. J. Agri. Innovation Res. 1(1):7-11.

Rao BN, Manhar MS. (1990) . Effect of sowing time on yield and quality of radish Raphanus Sativas L. cultivars. Horticultural Science Journal.; 19(3\&4):333-336.

Anouymous . (2001) . SAS Users Guide , Personal Computers. Inst . Inc . Cary . N.C.

Sandler, L.; Nelson, K. A.; and Dudenhoeffer, C. J. (2015). Radish planting date and nitrogen rate for cover crop production and the impact on corn yields in upstate missouri. J. Agri. Sci. 7(6): 1-13.

Sharma, D. K.; Chadha, S.; Kumar, S. S. and Chaudhary, D. R. (2007). Effect of sowing time on the performance of radish (Raphanus sativus L.) cultivars under low hills of Himachal Pradesh. Himachal J. Agric. Res. 33(1): 36-39.

Singh, K. P.; Kumar, R.; Sohane, R. K. and Das, A. K. (2015). Performance of early cauliflower variety sabour agrim vis a vis different dates of transplanting in arwal district of bihar. J Krishi Vigyan 4(1): 84-87.

Singh, V.B. and R.K. Taj, (2005) . Evaluation of radish cultivars under rain fed conditions of Nagaland. Prog. Horti. 37 (1): 72-74.

Sridhar . (1998). Evaluation of radish cultivars in South Andaman. Progressive Horticulture. (3/4): 217-220.

Thamburaj, S. and Singh N. (2005). Vegetables, Tuber Crops and Spices. New Delhi: Indian council of Agriculture Research. pp 40.

Jilani. M S; T. Burki and Kashif. W. (2010).effect of nitrogen on growth and yield of radish J. Agric Res. 48(2):219-225. 